\title{
SEROPREVALENSI HEPATITIS B PADA PEMULUNG SAMPAH DI \\ KOTA PALANGKA RAYA
}

Seroprevalence of Hepatitis B Virus Infection among Waste Pickers in Palangka Raya

\author{
Suratno ${ }^{1^{*}}$ \\ Fera Sartika ${ }^{1}$ \\ *1Program Studi Analis Kesehatan, Fakultas IImu Kesehatan, Universitas Muhammadiyah \\ Palangkaraya, Palangka Raya, KalimantanTengah, Indonesia \\ *email: nono.suratno89@yahoo.com
}

\begin{abstract}
Abstrak
Hepatitis B merupakan infeksi Virus Hepatitis B atau Hepatitis B virus (HBV) yang dapat menyerang hati dan menyebabkan penyakit akut dan kronis. Kelompok yang paling rentan terhadap penularan hepatitis B adalah pemulung sampah. Penelitian ini bertujuan untuk mengetahui: (1) tingkat infeksi virus Hepatitis B pada pemulung sampah yang bekerja di beberapa TPS di kota Palangka Raya, dan (2) faktor resiko infeksi virus Hepatitis B pada pemulung sampah yang bekerja di beberapa TPS di kota Palangka Raya. Penelitian ini merupakan penelitian observasional analitik dengan dengan menggunakan desain cross sectional study. Pemilihan sampel menggunakan teknik Purposive Sampling yang melibatkan sampel pemulung sampah di Palangka Raya sebanyak 32 orang. Pemeriksaan skrining hepatitis B melalui tes HbsAg kepada sampel darah pemulung sampah menggunakan metode Rapid Test. Hasil penelitian menunjukkan bahwa tingkat infeksi hepatitis B berdasarkan pemeriksaan HBsAg positif yaitu sebanyak 3,1\% responden (1 orang). Faktor resiko penularan atau paparan hepatitis $B$ yang berkaitan langsung aktivitas pemulung sampah adalah tidak menggunakan Alat Pelindung Diri (APD) sarung tangan dan cara pengambilan sampah dengan tangan kosong, masing-masing $3,6 \%$ dan $6,7 \%$.
\end{abstract}

Kata Kunci: Pemulung sampah, Hepatitis B, HBsAg 


\begin{abstract}
Hepatitis $B$ is a hepatitis $B$ virus (HBV) infection which can exacerbate the liver and cause acute and chronic disease. The most susceptible group to hepatitis $B$ transmission is waste pickers. This study aimed to determine: (1) the level of Hepatitis $B$ virus infection among waste pickers in several temporary waste shelters in Palangka Raya, and (2) risk factors for hepatitis $B$ virus infection in waste pickers in several temporary waste shelters in Palangka Raya. The observational analytic study using a cross sectional study design were used in this research. The purposive sampling technique was carried out to involve 32 waste pickers in Palangka Raya. Examination of hepatitis $B$ screening through HBsAg test to waste scavenger blood samples using the Rapid Test method. The results showed that the rate of hepatitis B infection based on positive HBsAg examination was 3.1\% of respondents. Risk factors for transmission or exposure to hepatitis $B$ that are directly related to the activity of garbage scavengers are not using protective equipment (PPE) gloves and bare hands waste collection, respectively $3.6 \%$ and $6.7 \%$
\end{abstract}

Keywords: Waste pickers, Hepatitis $B, H B s A g$

\section{PENDAHULUAN}

Hepatitis B merupakan infeksi Virus Hepatitis B atau Hepatitis $B$ virus (HBV) yang dapat menyerang hati dan menyebabkan penyakit akut dan kronis. HBV ditularkan melalui kontak dengan darah atau cairan tubuh lain dari orang yang terinfeksi seperti melalui kontak seksual, transfusi darah, injeksi yang tidak aman, juga melalui perinatal (dari ibu ke bayi saat kelahiran). HBV lebih infeksius 50-100 kali dibanding Human Immunodeficiency Virus (HIV), virus penyebab penyakit Acquired Immune Deficiency Syndrome (AIDS). Hepatitis $B$ dapat dicegah melalui vaksin yang aman dan efektif [1].

Berdasarkan Refrensi [2] Tahun 2018, prevalensi hepatitis $\mathrm{B}$ berdasarkan diagnosis dokter di Indonesia meningkat dari 0,2\% pada tahun 2013 menjadi 0,4\% pada tahun 2018. Begitu pula dengan di provinsi Kalimantan Tengah, prevalensi hepatitis $B$ juga meningkat dari 0,2\% pada tahun 2013 menjadi 0,4\% pada tahun 2018.
Kelompok yang paling rentan terhadap penularan hepatitis $B$ adalah pemulung sampah. Kondisi tempat kerja yang sangat kumuh dan berbau merupakan sumber berbagai penyakit yang berpotensi menyerang para pemulung Potensi penyakit yang ada adalah ISPA (Infeksi Saluran Pernapasan Atas), alergi kulit, radang paru-paru, asma, anemia dan lain-lain. Potensi penularan oleh penyakit infeksi seperti Hepatitis B, HIV/AIDS atau penyakit lainnya juga cukup tinggi. Penularan tersebut dapat terjadi melalui jarum suntik yang tertusuk ke tangan ataupun ke telapak kaki [3]. Resiko kesehatan yang dapat terjadi semakin diperparah dengan tidak dipergunakannya Alat Pelindung Diri (APD) pada saat bekerja yang sangat sederhana seperti sepatu, topi, masker, sepatu booth dan lain-lain, yang tidak memenuhi persyaratan sebagai pelindung yang dapat memberikan keamanan dan kenyamanan terhadap ancaman gangguan kesehatan. 
Seroprevalensi dan resiko penularan hepatitis B pada pemulung sampah serta terbatasnya penelitian tentang hepatitis $B$ yang berhubungan dengan faktor resiko kejadian hepatitis $B$ pada pemulung sampah di Indonesia khususnya kota Palangka Raya, menjadi dorongan peneliti untuk melihat hal tersebut.

\section{METODOLOGI}

Penelitian ini merupakan penelitian observasional analitik dengan dengan menggunakan desain cross sectional study. Pemilihan sampel menggunakan teknik Purposive Sampling yang melibatkan sampel pemulung sampah di Palangka Raya sebanyak 32 orang.

Penelitian yang dilaksanakan terbagi menjadi beberapa tahapan penelitian yang berkesinambungan, yaitu sebagai berikut:

1. Permintaan Kesediaan Menjadi Sampel (Informed Consent), dimana Lembar Informed Consent ini dilakukan untuk menjamin subjek penelitian (pemulung sampah) mendapat penjelasan yang baik sebelum pengambilan sampel darah.

2. Survei Faktor Resiko, dimana analisis faktor resiko penularan hepatitis $B$ dilakukan melalui angket yang berisi faktor-faktor resiko infeksi hepatitis $B$ pada pemulung sampah seperti identitas, tingkat pendidikan, Kecelakaan kerja di TPS, tertusuk jarum bekas, penggunaan APD, aplikasi tatto permanen, penggunaan narkoba, hubungan seksual, riwayat keluarga, riwayat vaksinasi, riwayat transfusi darah, riwayat operasi, riwayat cukur rambut, dan lain-lain.
3. Pengambilan Sampel Darah Vena dan Pemeriksaan HbsAg, dilakukan Pemilihan sampel menggunakan teknik Purposive Sampling. Jumlah sampel pemulung sampah di Palangka Raya yang terlibat dalam penelitian ini sebanyak 32 orang.

4. Pemeriksaan skrining $\mathrm{HbsAg}$, dilakukan kepada sampel darah pemulung sampah menggunakan metode Rapid Test. Ini dilakukan untuk mengetahui tingkat infeksi virus Hepatitis B pada kalangan pemulung sampah di TPS di kota Palangka Raya. Prosedur: Sentrifuse darah vena tanpa EDTA selama 5 menit dengan kecepatan 3000 rpm. Setelah diperoleh serum, pisahkan serum kedalam tabung reaksi lainnya menggunakan mikropipet. Masukkan strip test HBsAg kedalam tabung yang berisi serum tersebut dengan arah panah ke bawah. Catatan: batas serum tidak boleh melebihi tanda batas maksimum pada strip test. Tunggu 10-15 menit, kemudian amati terbentuknya garis pada strip test.

\section{HASIL DAN PEMBAHASAN}

Berdasarkan penelitian yang telah dilakukan diperoleh sebanyak 32 orang pemulung yang bersedia menjadi responden dari sebanyak 39 orang pemulung yang dimintai kesediaan menjadi responden.

Tabel 1. Karakteristik sampel

\begin{tabular}{cccc}
\hline $\begin{array}{c}\text { Karakteri } \\
\text { stik }\end{array}$ & Klasifikasi & Juml & Persent \\
& & (N) & ase (\%) \\
\hline
\end{tabular}

\begin{tabular}{llll}
\hline Jenis & Perempua & & \\
Kelamin & $\mathrm{n}$ & 19 & 59,4 \\
& Laki-laki & 13 & 40,6
\end{tabular}


Seroprevalensi Hepatitis B Pada Pemulung Sampah Dí Kota Palangka Raya (Seroprevalence of Hepatitís $\mathcal{B}$ Virus Infection among Waste Píckers in Palangka Raya)

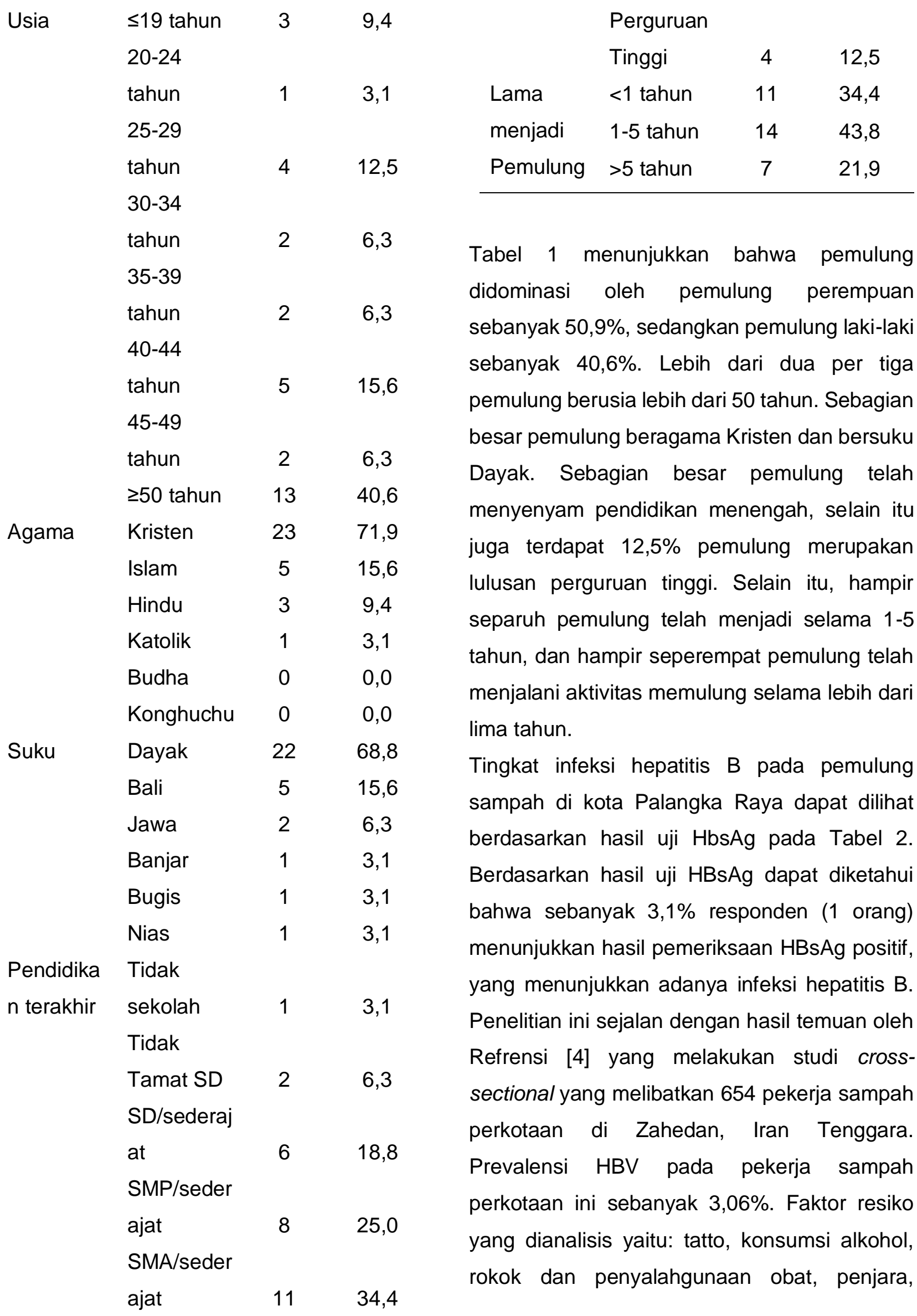


penyakit kuning, transfusi darah, operasi bedah, endoskopi, perawatan gigi, dan lain-lain.

Tabel 2. Hasil uji HBsAg pada pemulung sampah

\begin{tabular}{ccccc}
\cline { 2 - 3 } $\begin{array}{c}\text { Hasil } \\
\text { Pemeriksaan } \\
\text { HBsAg }\end{array}$ & \multicolumn{2}{c}{$\begin{array}{c}\text { Jenis } \\
\text { Kelamin }\end{array}$} & $\begin{array}{c}\text { Jumlah } \\
\mathbf{( N )}\end{array}$ & $\begin{array}{c}\text { Presentase } \\
\text { (\%) }\end{array}$ \\
\cline { 2 - 3 } & $\mathbf{L}$ & $\mathbf{P}$ & & \\
\hline Positif & 1 & 0 & & 3,1 \\
Negatif & 12 & 19 & 31 & 96,9 \\
Total & 13 & 19 & 32 & 100 \\
\hline
\end{tabular}

Temuan penelitian ini menunjukkan bahwa terdapat kaitan antara aktivitas pemulung sampah dengan kejadian hepatitis di kota Palangka Raya. Sebuah studi meta-analisis yang dilakukan oleh Refrensi [5] menunjukkan bahwa secara statistik terdapat kaitan yang kuat antara paparan sampah, baik medis ataupun rumah tangga, dan marker infeksi HBV positif. Prevalensi HBV pada pengumpul sampah di Tempat Pembuangan Akhir (TPA) Sampah Terbuka di kota metropolitan Rio de Janeiro, Brazil sebanyak 12,3\%, serta faktor resiko yang terkait dengan infeksi HBV [6]. Sebanyak 1,2\% pekerja pengumpul sampah di Belo Horizonte, Brazil, yang pernah terlibat kecelakaan kerja terkait sampah dinyatakan positif $\mathrm{HbsAg}$ (hepatitis B). Dan 0,6\% pekerja pengumpul sampah yang pernah terkena cipratan sampah dinyatakan positif $\mathrm{HbsAg}$ (hepatitis B) [5].
Tabel 3 menunjukkan bahwa hampir separuh pemulung sampah di kota Palangka Raya pernah mengalami kecelakaan kerja saat di Tempat Pembuangan Sampah Sementara atau TPS, sebagian pemulung pernah mengalami tertusuk jarum suntik. Jarum suntik bekas yang terpapar VHB sangat berbahaya dalam penularan hepatitis B. Hasil penelitian Refrensi [7] menyatakan paparan pekerja pada sampah adalah suatu faktor resiko yang memungkinkan terjadinya infeksi HBV. Kecelakaan kerja dengan alat yang tajam dapat menyebabkan penularan virus hepatitis $B$. Prevalensi infeksi HBV pada pekerja pengumpul sampah sebanyak 23\%. Bahkan, pengumpul sampah yang terlapor mengalami kecelakaan kerja dengan jarum suntik mempunyai resiko infeksi HBV yang lebih tinggi. 
Seroprevalensi Hepatitis B Pada Pemulung Sampah Di Kota Palangka Raya (Seroprevalence of Hepatitís $\mathcal{B}$ Virus Infection among Waste Píckers in Palangka Raya)

Tabel 3. Faktor resiko hepatitis B pada pemulung sampah

\begin{tabular}{|c|c|c|c|c|c|}
\hline Faktor Resiko & Variabel & Jumlah & Persentase (\%) & $\begin{array}{l}\text { HBsAg } \\
\text { reaktif }\end{array}$ & $\begin{array}{c}\text { Persentase } \\
\text { HBsAg } \\
\text { positif/total (\%) }\end{array}$ \\
\hline \multirow[t]{2}{*}{ Jenis Kelamin } & Laki-laki & 13 & 40,6 & 1 & 7,7 \\
\hline & Perempuan & 19 & 59,4 & 0 & 0 \\
\hline \multirow[t]{3}{*}{ Lama menjadi Pemulung } & $<1$ tahun & 11 & 34,4 & 1 & 9,1 \\
\hline & $1-5$ tahun & 14 & 43,8 & 0 & 0 \\
\hline & $>5$ tahun & 7 & 21,9 & 0 & 0 \\
\hline \multirow[t]{2}{*}{ Kecelakaan Kerja di TPS } & Pernah & 14 & 43,8 & 0 & 0 \\
\hline & Tidak Pernah & 18 & 56,3 & 1 & 5,6 \\
\hline \multirow[t]{5}{*}{ Cara pengambilan sampah } & Tangan kosong & 15 & 46,9 & 1 & 6,7 \\
\hline & Sarung tangan & 4 & 12,5 & 0 & 0 \\
\hline & Pelindung tangan & & & & \\
\hline & plastik & 5 & 15,6 & 0 & 0 \\
\hline & Penjepit/stick & 8 & 25 & 0 & 0 \\
\hline \multirow[t]{2}{*}{ Tatto permanen } & Pernah & 2 & 6,3 & 0 & 0 \\
\hline & Tidak pernah & 30 & 93,8 & 1 & 3,3 \\
\hline \multirow[t]{2}{*}{ Riwayat Keluarga Hepatitis B } & Ada & 1 & 3,1 & 0 & 0 \\
\hline & Tidak Ada & 31 & 96,9 & 1 & 3,2 \\
\hline \multirow[t]{2}{*}{ Penggunaan APD - Sepatu } & Pakai & 17 & 53,1 & 1 & 5,9 \\
\hline & Tidak Pakai & 15 & 46,9 & 0 & 0 \\
\hline Penggunaan APD - Sarung & Pakai & 4 & 12,5 & 0 & 0 \\
\hline Tangan & Tidak Pakai & 28 & 87,5 & 1 & 3,6 \\
\hline \multirow[t]{2}{*}{ Vaksinasi Hepatitis B } & Pernah & 8 & 25 & 0 & 0 \\
\hline & Tidak pernah & 24 & 75 & 1 & 4,2 \\
\hline \multirow[t]{2}{*}{ Transfusi Darah } & Pernah & 6 & 18,8 & 0 & 0 \\
\hline & Tidak Pernah & 26 & 81,2 & 1 & 3,8 \\
\hline \multirow[t]{2}{*}{ Operasi } & Pernah & 8 & 25 & 0 & 0 \\
\hline & Tidak pernah & 24 & 75 & 1 & 4,2 \\
\hline \multirow[t]{2}{*}{ Cukur rambut di tempat cukur } & Pernah & 32 & 100 & 1 & 3,1 \\
\hline & Tidak pernah & 0 & 0 & 0 & - \\
\hline \multirow[t]{2}{*}{ Narkoba suntik } & Pernah & 0 & 0 & 0 & - \\
\hline & Tidak pernah & 32 & 100 & 1 & 3,1 \\
\hline \multirow[t]{2}{*}{ Hubungan seksual } & Pernah & 29 & 90,6 & 1 & 3,4 \\
\hline & Tidak pernah & 3 & 9,4 & 0 & 0 \\
\hline \multirow[t]{2}{*}{ Cabut/tambal gigi } & Pernah & 11 & 34,4 & 0 & 0 \\
\hline & Tidak pernah & 21 & 65,6 & 1 & 4,8 \\
\hline \multirow[t]{2}{*}{ Merokok } & $\mathrm{Ya}$ & 13 & 40,6 & 1 & 7,7 \\
\hline & Tidak & 19 & 59,4 & 0 & 0 \\
\hline \multirow[t]{2}{*}{ Konsumsi alkohol } & $\mathrm{Ya}$ & 5 & 15,6 & 0 & 0 \\
\hline & Tidak & 27 & 84,4 & 1 & 3,7 \\
\hline
\end{tabular}


Prevalensi hepatitis B pada pemulung sampah di Karachi, Pakistan, sebanyak $18,8 \%$. Faktor penting yang menyebabkan prevalensi tinggi hepatitis $\mathrm{B}$ dan $\mathrm{C}$ adalah kecelakaan tertusuk jarum, pengumpulan sampah dengan tangan kosong dan kaki tanpa pelindung, status vaksinasi yang rendah, sistem

pembuangan sampah yang tidak layak dan kondisi tempat pengumpulan sampah [8].

Berdasarkan Tabel 3 juga dapat diketahui bahwa terdapat 1 orang dengan hasil pemeriksaan HBsAg positif, faktor resiko penularan atau paparan hepatitis B yang berkaitan langsung aktivitas pemulung sampah adalah tidak menggunakan Alat Pelindung Diri (APD) sarung tangan dan cara pengambilan sampah dengan tangan kosong, masing-masing $3,6 \%$ dan $6,7 \%$. Faktor resiko ini sangat erat kaitannya terhadap penularan hepatitis B melalui sampah yang ada di TPS tempat pemulung melakukan aktivitasnya.

Prevalensi Hepatitis B pada pengguna narkoba suntik di Indonesia sebanyak 2,9\% [9]. Refrensi [13] melakukan penelitian tingkat infeksi Hepatitis B yang melibatkan 152 pekerja limbah medis dan 82 pekerja limbah non-medis di Etiopia Selatan. Hasil penelitian menunjukkan bahwa infeksi HBV lebih tinggi terjadi pada pekerja limbah medis dibanding non medis. Di antara pekerja limbah medis sebanyak $58.6 \%$ dicurigai terinfeksi hepatitis B. Pada penelitian ini juga dikaji mengenai faktor resiko infeksi hepatitis B pada pekerja limbah medis, seperti: terkena jarum suntik, paparan air liur, operasi bedah, transfusi darah, riwayat penyakit hati, tatto, pencabutan gigi, seks lebih dari satu pasangan, riwayat penyakit hati keluarga, dan lain-lain.

Selain itu, faktor resiko paparan hepatitis B pada responden dengan hasil pemeriksaan HBsAg positif juga adalah tidak melakukan vaksinasi Hepatitis B yaitu 4,2\%. Vaksinasi sangat penting dalam mencegah penularan atau paparan hepatitis B pada pemulung sampah. Refrensi [11] menyimpulkan bahwa pekerja yang menangani sampah perlu divaksinasi terhadap infeksi HBV karena mereka beresiko tertular infeksi melalui paparan sampah yang berpotensi terinfeksi HBV.

\section{KESIMPULAN}

Tingkat infeksi hepatitis B berdasarkan pemeriksaan HBsAg positif yaitu sebanyak $3,1 \%$ responden (1 orang) dari 32 responden yang diperiksa. Faktor resiko penularan atau paparan hepatitis $B$ yang berkaitan langsung aktivitas pemulung sampah adalah tidak menggunakan Alat Pelindung Diri (APD) sarung tangan dan cara pengambilan sampah dengan tangan kosong, masingmasing $3,6 \%$ dan $6,7 \%$. 
Seroprevalensi Hepatitis $\mathcal{B}$ Pada Pemulung Sampah Di Kota Palangka Raya (Seroprevalence of Hepatitís $\mathcal{B}$ Virus Infection among Waste Pickers in Palangka Raya)

\section{UCAPAN TERIMA KASIH}

Penulis mengucapkan terima kasih kepada pihak Lembaga Penelitian dan Pengabdian kepada Masyarakat (LP2M) Universitas Muhammadiyah Palangkaraya yang telah mendanai kegiatan ini melalui hibah penelitian dengan skema Penelitian Kompetitif Dosen Internal (PKDI) Tahun 2019. Sesuai dengan Surat Perjanjian Penugasan Pelaksanaan Penelitian Nomor 019.e/PTM.63.R10/LP2M/N/2019 Tanggal 23 Mei 2019.

\section{DAFTAR PUSTAKA}

1. WHO. 2011. Viral Hepatitis in the WHO South-East Asia Region. World Health Organization Regional Office for South-East Asia. India.

2. Kemenkes RI. 2018. Riset Kesehatan Dasar; RISKESDAS. Balitbang Kemenkes RI. Jakarta.

3. Herlinda. 2010. Persepsi Pemulung terhadap Risiko Kesehatan Dan Keselamatan Kerja Dikaitkan dengan Penggunaan Alat Pelindung Diri (APD) di Tempat Penampungan Sampah Sementara (TPS) Tegallega. Tesis. Jakarta: Universitas Indonesia.

4. Ansari-Moghaddam, A., H. Ansari, S. Khosravi, E. Sanei-Moghaddam, M. Mohammadi, S.M. Alavian, \& $\mathrm{H}$. Poustchi. 2016. The Prevalence of Hepatitis B Virus Among Municipal
Solid WasteWorkers: Necessity for Immunization of At-Risk Groups. Hepat Mon 16(3): 1-6.

5. Mol, M.P.G., S. Cairncross, D.B. Greco, \& L. Heller. 2017. Is waste collection associated with hepatitis $B$ infection? A meta-analysis. Rev Soc Bras Med Trop 50(6):756-763.

6. Klein, G., T.K.R. Botelho, C.M.M. de Cordova, \& A. do Livramento. 2018. High prevalence of HBV carriers among waste collectors in the largest landfill in Latin America. Rev Patol Trop 47(1): 5-10.

7. Rachiotis, G., D. Papagiannis, D. Markas, E. Thanasias, G. Dounias, \& C. Hadjichristodoulou. 2012. Hepatitis B Virus Infection and Waste Collection: Prevalence, Risk Factors, and Infection Pathway. American Journal Of Industrial Medicine, 1-6.

8. Rauf, M.U.A., M.D. Saleem, M.O. Anwer, G. Ahmed, S. Aziz, \& M.A. Memon. 2013. HIV, Hepatitis B and Hepatitis $C$ in garbage scavengers of Karachi. J Pak Med Assoc 63(6): 798-802.

9. Nelson, P., B. Mathers, B. Cowie, $H$. Hagan, D.D. Jarlais, D.Horyniak, \& L. Degenhardt. 2011. Global epidemiology of hepatitis $B$ and hepatitis $C$ in people who inject drugs: results of systematic reviews. Lancet 378: 571-83. 
Seroprevalensi Hepatitís $\mathcal{B}$ Pada Pemulung Sampah Dí Kota Palangka Raya (Seroprevalence of Hepatitís $\mathcal{B}$ Virus Infection among Waste Píckers in Palangka Raya)

10. Amsalu, A., M. Worku, E. Tadesse, \& T. Shimelis. 2016. The exposure rate to hepatitis $B$ and $C$ viruses among medical waste handlers in three government hospitals, southern Ethiopia. Epidemiology and Health 38:1-8.
11. Corrao, CRN., Del Cimmuto, A., Marzuillo, C., Paparo, E., \& La Torre, G. 2013 Association between Waste Management and HBV among Solid Municipal Waste Workers: A Systematic Review and MetaAnalysis of Observational Studies. The Scientific World Journal. 1-5. 